\title{
Reversal of Impaired GIP and Insulin Secretion in Patients with Pancreatogenic Steatorrhea Following Enzyme Substitution
}

\author{
R. Ebert and W. Creutzfeldt \\ Division of Gastroenterology and Metabolism, Department of Medicine, University of Göttingen, Göttingen, FRG
}

Summary. The influence of impaired digestion on nutrient induced release of gastric inhibitory polypeptide (GIP) and insulin have been investigated in patients with chronic pancreatitis. All patients had massive steatorrhea ( $>25 \mathrm{~g} / 24 \mathrm{~h}$ ), and glucose intolerance. A standard liquid test meal comprising fat and glucose were ingested with or without pancreatic enzyme substitution ( $9.0 \mathrm{~g}$ pancreatin). In the presence of pancreatin the response of serum levels of GIP to the test meal was significantly enhanced ( 81.2 vs $194.5 \mu \mathrm{g} / 1 \times 180 \mathrm{~min})$. Concurrently, the insulin response was augmented $(3.4 \mathrm{vs} 6.4 \mathrm{U} / 1 \times 180 \mathrm{~min})$, resulting in improved glucose tolerance. Addition of pancreatin also significantly augmented the GIP response to oral fat $(100 \mathrm{~g})$, but not to oral glucose $(100 \mathrm{~g})$. In patients with pancreatogenic steatorrhea the insulin response to an IV glucose infusion $(0.7 \mathrm{~g} /$ $\mathrm{kg} / \mathrm{h}$ for $90 \mathrm{~min}$ ) was augmented by oral fat only after addition of $9.0 \mathrm{~g}$ pancreatin to the fat load (3.5 vs $7.3 \mathrm{U} / 1 \times 180 \mathrm{~min})$. After restoration of the GIP response to fat by pancreatin, the inhibitory effect of IV glucose on fat-induced GIP increase was restored. These data indicate that the GIP response to a mixed meal or triglycerides is dependent on the absorption of nutrients. In patients with chronic pancreatitis improvement of pancreatogenic insufficiency reverses the impaired GIP response, restores the incretin effect of fat, and improves glucose tolerance.

Key words: GIP release, chronic pancreatitis, steatorrhea, maldigestion, pancreatin, incretin effect.

The ingestion of glucose leads to a rapid and sharp rise in the serum levels of gastric inhibitory poly- peptide (GIP) [1-3]. Galactose [4, 5], triglycerides $[1,3,5,6]$ and certain amino acids [7] given orally, also stimulate the secretion of GIP, whilst GIP itself potentiates glucose induced release of insulin [8-10]. The mechanisms underlying the release of GIP are poorly understood. It has been suggested that the secretion of GIP occurs during the process of absorption $[1,11]$. In patients with coeliac disease and severe malabsorption a test meal evokes only a weak GIP response compared to normal subjects $[11,12]$. Since the number of GIP cells is not reduced in coeliac disease $[11,13]$ defective absorption could explain the diminished GIP release. In patients with chronic pancreatitis impaired fat digestion decreases GIP release while impaired insulin secretion enhances GIP secretion [14]. In patients with mild steatorrhea the GIP response to a test meal is abnormally high because the insulin secretion is diminished. In patients with severe steatorrhea the GIP response is much smaller despite of the presence of subclinical or overt diabetes with severely impaired insulin secretion [14]. These studies indicate the amount of GIP released after ingestion of a mixed test meal in chronic pancreatitis is determined by at least two factors: the degree of the remaining insulin secretion and the degree of digestion and consecutive absorption of nutrients. To evaluate further the role of impaired digestion in GIP secretion the response of GIP to a mixed test meal or fat was studied in patients with chronic pancreatitis and massive steatorrhea, with and without pancreatic enzyme substitution. Since GIP is presently regarded as the strongest candidate for the gut factor which augments the glucose-induced insulin release ("incretin") [15], the effect of improvement of digestion by enzyme supplementation on the incretin effect of oral fat was also examined. 


\section{Methods}

\section{Subjects}

Twenty-four subjects with chronic pancreatitis and 21 healthy subjects volunteered for the studies. Informed consent was obtained from all subjects. The healthy volunteers, all within $10 \%$ of ideal body weight.(Metropolitan Life Insurance Tables) [21], mean weight $62 \mathrm{~kg}$ ( 4 females, 17 males; mean age 17 years, range 19-37) served as controls. All had normal oral glucose tolerance, the 60 plus 120 min sum of blood glucose levels after ingestion of $75 \mathrm{~g}$ glucose being below $290 \mathrm{mg} / \mathrm{dl}$ [24]. All had consumed not less than $200 \mathrm{~g}$ carbohydrate per day until the evening before the tests.

Chronic pancreatitis was diagnosed by marked reduction of bicarbonate and enzyme secretion as demonstrated by the secretin-pancreozymin test. All patients had at least two or more attacks of pancreatitis. Alcohol was an aetiological factor in nineteen patients with no apparent cause in the rest. Seventeen patients had radiologically ascertained pancreatic calcification. All patients excreted more than $25 \mathrm{~g}$ fat $/ 24 \mathrm{~h}$ in the absence of pancreatic enzyme supplementation. Pancreatin treatment, $16 \mathrm{~g}$ per day, decreased mean fat excretion to $9 \pm 1 \mathrm{~g} / 24 \mathrm{~h}$. No patient had a family history of diabetes. All patients had a pathological oral glucose tolerance, the 60 plus $120 \mathrm{~min}$ sum of blood glucose levels after ingestion of $75 \mathrm{~g}$ glucose being above $310 \mathrm{mg} / \mathrm{dl}$ [24], but none had overt diabetes or fasting blood glucose levels above $130 \mathrm{mg} / \mathrm{dl}$. Mean age ( 5 females, 19 males) was 40 years (range $24-58$ ), mean weight $59.7 \pm 3.1 \mathrm{~kg}$ and the average deviation from the ideal body weight $-13.8 \%$. No subject had renal impairment, as assessed by routine laboratory tests, or other gastrointestinal disturbances, or was taking medication known to interfere with carbohydrate tolerance. All had consumed not less than $200 \mathrm{~g}$ carbohydrate per day without any caloric restriction.

\section{Protocol}

All tests were performed after an overnight fast. A plastic catheter for blood sampling was inserted into an antecubital vein, and patency was maintained by slow infusion of saline $(0.154 \mathrm{~mol} / \mathrm{l})$. Three fasting blood samples were withdrawn; further blood samples were collected after nutrient ingestion every $15 \mathrm{~min}$ for $60 \mathrm{~min}$ and every $30 \mathrm{~min}$ thereafter. Samples were immediately placed on ice and centrifuged at $4{ }^{\circ} \mathrm{C}$. Five aliquots of each serum sample were frozen and stored at $-20^{\circ} \mathrm{C}$ until assayed.

1. Test Meal. The liquid test meal contained $152 \mathrm{~g}$ carbohydrate (18 g glucose, $14 \mathrm{~g}$ maltose, $12 \mathrm{~g}$ maltotriose, $52 \mathrm{~g}$ lactose, $56 \mathrm{~g}$ oligosaccharides), $30 \mathrm{~g}$ fat $(100 \mathrm{ml} \mathrm{cream})$ and $36 \mathrm{~g}$ protein (milk powder) in a total volume of $550 \mathrm{ml} \mathrm{[11].} \mathrm{Blood} \mathrm{samples} \mathrm{were}$ obtained for $300 \mathrm{~min}$. On a second occasion the study was repeated with pancreatic enzyme supplementation. Five min before intake of the test meal the subjects ingested $9.0 \mathrm{~g}$ pancreatin as granules (Pankreon Granulat, Kali-Chemie, Hannover). The tests were performed in randomised order within two weeks in each subject.

2. Oral Glucose. Fourteen patients with chronic pancreatitis ingested $100 \mathrm{~g}$ glucose dissolved in $300 \mathrm{ml}$ water within five min. Blood samples were obtained for $180 \mathrm{~min}$. The test was repeated within one week with $9.0 \mathrm{~g}$ pancreatin, given $5 \mathrm{~min}$ before ingestion of the glucose solution.

3. Oral Fat Plus $V$ Glucose. In order to demonstrate the insulinotropic effect of an oral fat load IV glucose was infused starting at the time of fat ingestion. Indwelling cannulae were placed in each arm, one for blood sampling and the other for glucose administration. Blood samples were taken for $180 \mathrm{~min}$.
Nine subjects with chronic pancreatitis underwent the following tests on different occasions:

a) Oral fat load: The subjects ingested $150 \mathrm{ml}$ of a suspension of corn oil (Lipomul, Upjohn) corresponding to $100 \mathrm{~g}$ triglycerides, within five min.

b) Oral fat load plus $9.0 \mathrm{~g}$ pancreatin, $5 \mathrm{~min}$ before ingestion of the triglyceride suspension.

c) IV glucose infusion. Glucose $(10 \%$ solution in water) was administered for $90 \mathrm{~min}$ at a rate of $0.7 \mathrm{~g} / \mathrm{kg} / \mathrm{h}$.

d) IV glucose infusion plus $9.0 \mathrm{~g}$ pancreatin, given $5 \mathrm{~min}$ before start of the glucose infusion.

e) Oral fat load and IV glucose infusion for $90 \mathrm{~min}$.

f) Oral fat load plus $9.0 \mathrm{~g}$ pancreatin and IV glucose infusion for $90 \mathrm{~min}$.

\section{Laboratory Analyses}

Serum glucose was measured by the glucose oxidase method; serum insulin (IRI) was determined by radioimmunoassay using human insulin as standard [16]. Serum levels of immunoreactive GIP (IR-GIP) were measured according to Kuzio et al. [17], using rabbit GIP antiserum Gö 5/76/9. This antiserum has been characterised elsewhere [18]. The specific activity of ${ }^{125} \mathrm{I}$-GIP during this study was calculated to be $80-120 \mathrm{mCi} / \mathrm{mg}$ for the various iodinations. The lower limit of sensitivity of the GIP assay ranged from 6 to $12 \mathrm{pg}, 60$ to $120 \mathrm{pg} / \mathrm{ml}$ of serum. The interassay coefficient of variation $(\mathrm{CV})$ was $19.4 \%$ and the intra-assay CV $10.1 \%$, estimated from two GIP standards of 25 and $200 \mathrm{pg} / 100 \mu \mathrm{l}(\mathrm{n}=16)$. Porcine GIP was used as standard. The present GIP assay measures "big" and "little" GIP. By using Sephadex G-50 fine columns $(1 \times 200 \mathrm{~cm})$, alcoholic serum extracts could be separated into one peak at 7500-8000 Daltons and standard GIP (5100 Daltons) [1, 19]. One hour after either glucose or fat about one third of the IRGIP appeared as "big" and two thirds as "little" IR-GIP [19].

Stool fat was estimated in three consecutive $24 \mathrm{~h}$ stool collections both with and without pancreatic enzyme supplementation according to Van de Kamer [20] and steatorrhea expressed in $\mathrm{g} / 24 \mathrm{~h}$.

\section{Statistical Analysis}

All values are given as mean \pm SEM. Results were analysed using standard statistical methods. The two-tailed paired Student t-test was employed for comparison of the results with and without pancreatin. Integrated responses to the test meal, the fat and the glucose load for serum levels of glucose, IRI and IR-GIP were calculated from the sum of the products of the mean serum concentrations during each time period $\times \min$ in the time period, minus the basal value $x$ the total number of min after a test.

\section{Results}

\section{Response to Test Meal without and with Previous Intake of Pancreatin}

Figure 1 shows the serum levels of glucose, IRI and IR-GIP following ingestion of the mixed liquid test meal with and without pancreatin. In the absence of 

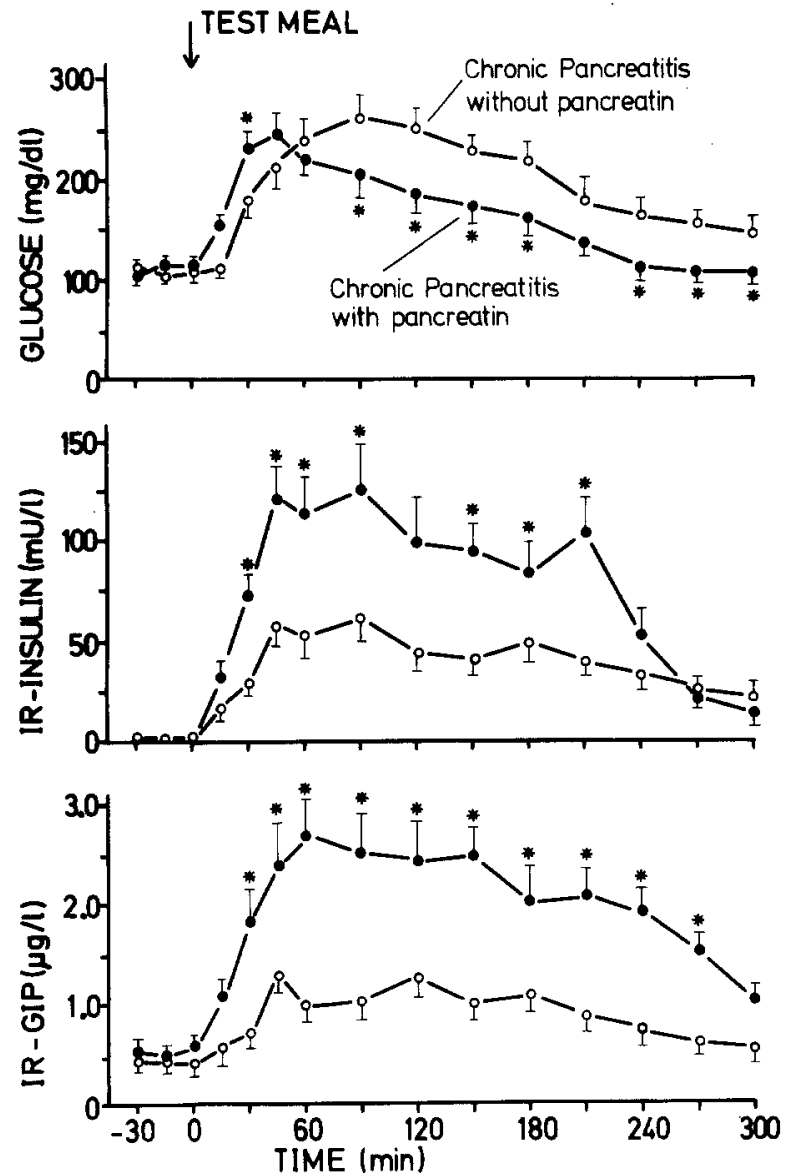

Fig. 1. Response of serum levels of IR-GIP, IRI and glucose to a liquid mixed test meal given at time zero in 16 patients with chronic pancreatitis and massive steatorrhea. The test was performed once without and on a second occasion with pancreatin $(9.0 \mathrm{~g})$, given $5 \mathrm{~min}$ before ingestion of the test meal. Asterisks indicate significant difference between the two tests $(p<0.05$ or less). - with pancreatin, $\mathrm{O}-\mathrm{O}$ without pancreatin

pancreatin a significant rise of IR-GIP was only observed after $30 \mathrm{~min}$ reaching a peak level of $1.45 \pm$ $0.25 \mu \mathrm{g} / 1$. After addition of pancreatin IR-GIP levels rose more rapidly and reached significantly greater peak levels $(2.59 \pm 0.21 \mu \mathrm{g} / \mathrm{l} ; \mathrm{p}<0.005)$.

Without pancreatin there was only a small mealinduced rise in plasma IRI $(61 \pm 9 \mathrm{mU} / 1$ at $45 \mathrm{~min})$. With pancreatin, IRI levels were significantly higher between 30 and $210 \mathrm{~min}$, reaching $122 \pm 18 \mathrm{mU} / \mathrm{l}$ at $45 \mathrm{~min}$. The patients with chronic pancreatitis had impaired glucose tolerance. Mean serum glucose levels were $230 \mathrm{mg} / \mathrm{dl}$ at $60 \mathrm{~min}$ and $242 \mathrm{mg} / \mathrm{dl}$ at 120 min. After pancreatin the serum glucose levels peaked earlier but fell again more rapidly.

The integrated responses of IR-GIP, IRI and glucose of controls and patients with chronic pancreatitis are shown in Table 1. The total IR-GIP and IRI
Table 1. Integrated responses ( $180 \mathrm{~min}$ ) of serum levels of IR-GIP, IRI and glucose to a test meal in normal subjects and in patients with pancreatogenic steatorrhea. The tests were performed with and without pancreatin $(9.0 \mathrm{~g})$. Results are given as mean $\pm \mathrm{SEM}$. See text for method of calculation

\begin{tabular}{llll}
\hline & $\begin{array}{l}\text { Serum IR-GIP } \\
(\mu \mathrm{g} / 1 \times 180 \mathrm{~min})\end{array}$ & $\begin{array}{l}\text { Serum IRI } \\
(\mathrm{U} / 1 \times 180 \mathrm{~min})\end{array}$ & $\begin{array}{l}\text { Serum glucose } \\
(\mathrm{g} / \mathrm{d} 1 \times 180 \mathrm{~min})\end{array}$ \\
\hline $\begin{array}{l}\text { Controls }(\mathrm{n}=14) \\
\begin{array}{l}\text { Chronic pancreatitis }(\mathrm{n}=16) \\
\text { without } \\
\text { pancreatin } \\
\text { with }\end{array}\end{array}$ & $8.0 \pm 0.9$ & $4.1 \pm 0.5$ \\
\begin{tabular}{l} 
pancreatin \\
\hline
\end{tabular} & $194 \pm 13^{\mathrm{b}}$ & $6.4 \pm 0.4^{\mathrm{a}}$ & $26.4 \pm 2.1^{\mathrm{a}}$ \\
\hline
\end{tabular}

${ }^{a} p<0.005$ between controls and patients with chronic pancreatitis ${ }^{b} p<0.01$ between patients with chronic pancreatitis with and without pancreatin

${ }^{c} \mathrm{p}<0.02$ between patients with chronic pancreatitis with and without pancreatin

Table 2. Integrated responses ( $180 \mathrm{~min}$ ) of serum levels of IR-GIP, IRI and glucose to a glucose load $(100 \mathrm{~g})$ in patients with chronic pancreatitis and in normal controls. In the pancreatitic subjects the test was performed with and without previous ingestion of pancreatin $(9.0 \mathrm{~g})$. Mean $\pm \mathrm{SEM}$

\begin{tabular}{llll}
\hline & $\begin{array}{l}\text { Serum } \\
\text { IR-GIP } \\
(\mu \mathrm{g} / 1 \times 180 \mathrm{~min})\end{array}$ & $\begin{array}{l}\text { Serum } \\
\text { IRI } \\
(\mathrm{U} / 1 \times 180 \mathrm{~min})\end{array}$ & $\begin{array}{l}\text { Serum } \\
\text { Glucose } \\
(\mathrm{g} / \mathrm{d} 1 \times 180 \mathrm{~min})\end{array}$ \\
\hline $\begin{array}{l}\text { Controls }(\mathrm{n}=15) \\
73 \pm 4\end{array}$ & $6.6 \pm 0.4$ & $7.5 \pm 0.5$ \\
$\begin{array}{l}\text { Chronic pancreatitis }(\mathrm{n}=8) \\
\text { without } \\
\text { pancreatin }\end{array}$ & $101 \pm 7$ & $2.4 \pm 0.2^{\mathrm{a}}$ & $25.1 \pm 1.9^{\mathrm{b}}$ \\
$\begin{array}{l}\text { with } \\
\text { pancreatin }\end{array}$ & $91 \pm 7$ & $2.9 \pm 0.4$ & $28.4 \pm 2.6$ \\
\hline
\end{tabular}

${ }^{\mathrm{a}} \mathrm{p}<0.01$ between controls and patients with chronic pancreatitis ${ }^{\mathrm{b}} \mathrm{p}<0.005$ between controls and patients with chronic pancreatitis

responses increased significantly after enzyme substitution in the pancreatitis patients, whereas the glucose response was significantly curtailed.

\section{Response to Oral Glucose}

The integrated responses of glucose, IRI and IR-GIP to the ingestion of $100 \mathrm{~g}$ glucose in patients with chronic pancreatitis are shown in Table 2. Compared to normal controls this group of pancreatitis patients showed a significantly diminished IRI output and a significantly increased glucose response although the GIP response was not significantly different. The ingestion of $9.0 \mathrm{~g}$ pancreatin did not significantly aiter the serum responses of IR-GIP, IRI and glucose to the oral glucose load. 


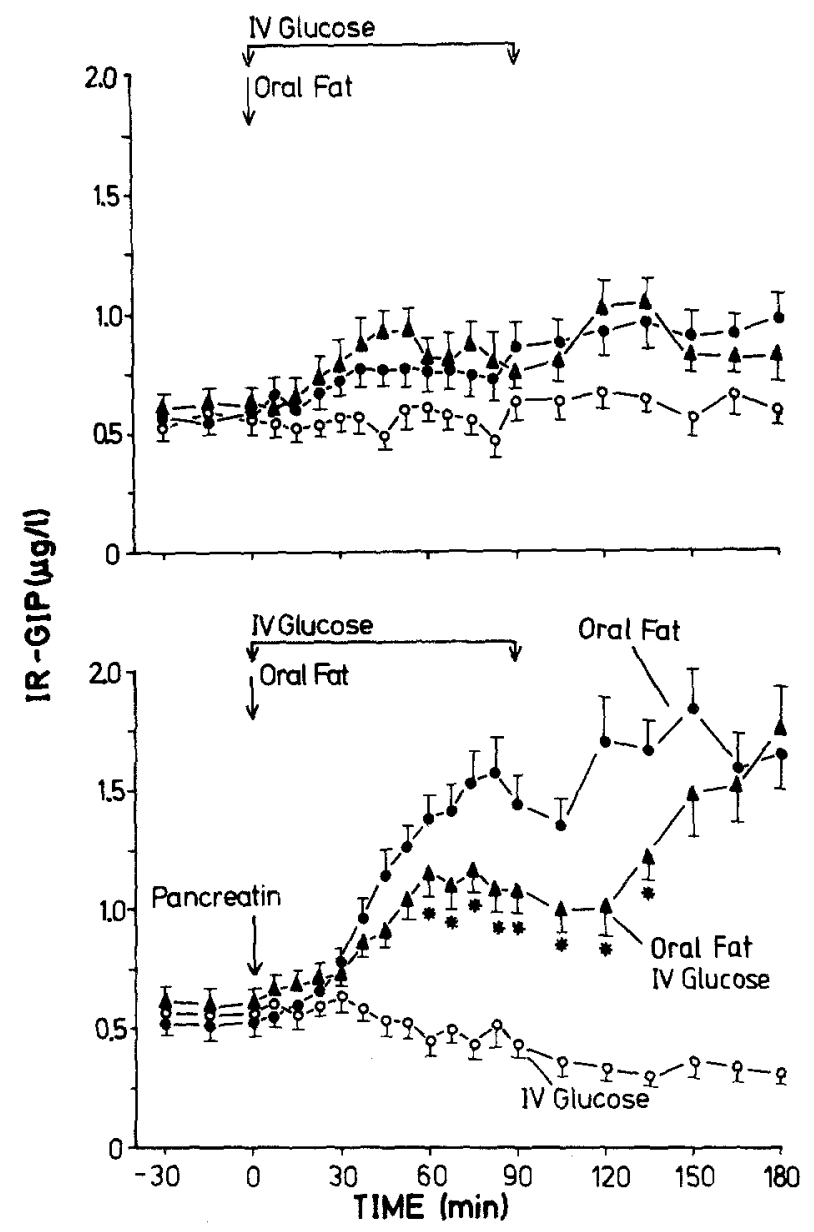

Fig. 2. Response of serum levels of IR-GIP in 9 patients with chronic pancreatitis to IV glucose infusion, triglyceride ingestion $(100 \mathrm{~g})$ and a combination of both. In the upper panel the tests were performed without and in the lower panel with pancreatin $(9.0 \mathrm{~g})$ given $5 \mathrm{~min}$ before the corresponding test. Glucose was infused at a rate of $0.7 \mathrm{~g} / \mathrm{kg} / \mathrm{h}$ over 90 minutes. Asterisks indicate significant difference between "oral fat" and "oral fat plus IV glucose" ( $p<0.05$ or less). oral fat, $\mathrm{O}-\mathrm{O}$ IV glucose, $\Delta-\mathbf{A}$ oral fat + IV glucose

\section{Response to a Combined Intravenous Glucose and Oral Fat Load}

The increase of IRI and IR-GIP during an IV glucose and oral fat load was compared before and after enzyme substitution with pancreatin. The subjects underwent 6 tests: oral fat $(100 \mathrm{~g})$, IV glucose $(0.7 \mathrm{~g} /$ $\mathrm{kg} / \mathrm{h}$ over $90 \mathrm{~min}$ ), and oral fat plus IV glucose each without and with enzyme substitution.

The IR-GIP responses to the different stimuli are shown in Figure 2. In the absence of pancreatin (upper panel of Figure 2) the oral fat load elicited only a moderate stimulation of IR-GIP secretion, levels remaining below $1 \mu \mathrm{g} / \mathrm{l}$. The IV glucose infusion did not change basal or stimulated serum concentrations of IR-GIP. After enzyme substitution

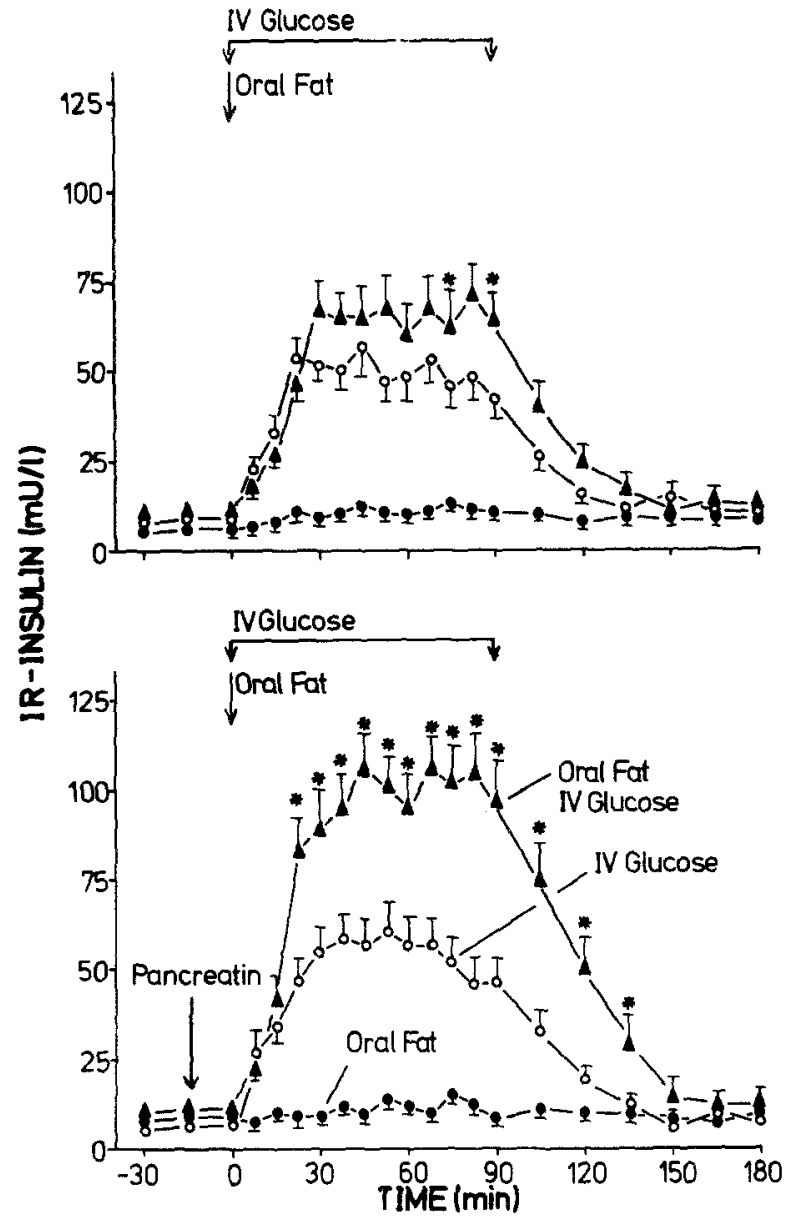

Fig. 3. Response of serum levels of IRI in 9 patients with chronic pancreatitis to IV glucose infusion $(0.7 \mathrm{~g} / \mathrm{kg} / \mathrm{h})$ over 90 minutes, triglyceride ingestion $(100 \mathrm{~g})$ and a combination of both. In the upper panel the tests were performed without and in the lower panel with pancreatin $(9.0 \mathrm{~g})$. Asterisks indicate significant difference between "IV glucose" and "oral fat plus IV glucose" $(p<0.05$ or less). - oral fat, $\mathrm{O}-\mathrm{O}$ IV glucose, $\boldsymbol{\Delta}-\boldsymbol{\Delta}$ oral fat $+\mathrm{IV}$ glucose

with $9.0 \mathrm{~g}$ pancreatin the IR-GIP response to oral fat was significantly enhanced to serum levels of $1.5 \mu \mathrm{g} / 1$. At the same time, IV glucose significantly inhibited the fat induced IR-GIP release. When the glucose infusion was stopped the IR-GIP levels slowly increased to $1.74 \pm 0.19 \mu \mathrm{g} / \mathrm{l}$ at $180 \mathrm{~min}$. The ingestion of pancreatin did not change basal levels of IRGIP during the IV load. Thereafter, basal IR-GIP levels decreased.

The integrated response of IR-GIP to oral fat was more than doubled by pancreatin (Table 3 ). The IV glucose infusion significantly lowered the fat induced IR-GIP output by $33 \%$ when pancreatin was given together with the fat load while no suppression was seen without pancreatin. 
Oral fat had no effect on serum IRI (Fig. 3). Infusion of glucose during $90 \mathrm{~min}$ raised the basal IRI levels to an average value of $50 \mathrm{mU} / \mathrm{l}$. When fat was ingested during the IV glucose infusion without pancreatin, the serum IRI concentrations increased moderately to an average value of $65 \mathrm{mU} / 1$. This effect was significant only at 70 and $90 \mathrm{~min}$. After addition of pancreatin the IRI release during the IV glucose infusion did not change, however, the combined IV glucose and oral fat load with pancreatin resulted in significantly higher IRI levels, reaching plateau values of about $100 \mathrm{mU} / \mathrm{l}$. The integrated response of IRI to IV glucose was enhanced by $20 \%$ following fat ingestion and more than doubled after ingestion of fat together with pancreatin (Table 3 ).

While pancreatin did not alter the integrated glucose response to IV glucose infusion this response was significantly diminished by pancreatin in the experiment with triglyceride load during the IV glucose infusion (Table 3).

\section{Discussion}

It has been suggested that absorption rather than the mere presence of nutrients in the gut lumen is the trigger for the release of GIP [11]. This suggestion was based on the observation that in coeliac disease the response of IR-GIP was drastically reduced after ingestion of a test meal or a glucose load [11, 12]. Moreover in rats the glucose-induced secretion of IRGIP was blocked when phlorizin, an inhibitor of active glucose transport, was added to intraduodenally infused glucose [22]. The present experiments in patients with chronic pancreatitis and massive steatorrhea underline the importance of digestion as a stimulus of GIP secretion. Improvement of digestion restores both the blunted IR-GIP response and IRI secretion in such patients.

The test meal in the above experiments consisted of glucose, disaccharides, oligosaccharides, fat and milk protein. Pancreatic enzymes improve digestion of several nutrients. Therefore the effect of pancreatin on fat induced IR-GIP release alone was also examined. Again, the secretion of IR-GIP was more than doubled when pancreatin was given shortly before the triglyceride load (Table 3). This GIP response was still less than in normal subjects after $100 \mathrm{~g}$ fat $(180 \pm 19 \mu \mathrm{g} / \mathrm{l} \times 180 \mathrm{~min})$ [23] corresponding to the fact that pancreatin improves but seldom renders fat absorption normal. This indicated that the diminished IR-GIP secretion in chronic pancreatitis with massive steatorrhea is related to exocrine insufficiency.

Fat has to be hydrolysed before GIP release is initiated. It has been demonstrated that long chain
Table 3. Integrated responses (180 min) of serum levels of IR-GIP, IRI and glucose in patients with pancreatogenic steatorrhea to the ingestion of oral triglyceride $(100 \mathrm{~g})$, IV glucose over $90 \mathrm{~min}(0.7 \mathrm{~g} /$ $\mathrm{kg} / \mathrm{h}$ ), and both together. All tests were performed with and without pancreatin $(9.0 \mathrm{~g})$. Mean $\pm \mathrm{SEM}$

\begin{tabular}{|c|c|c|c|}
\hline & $\begin{array}{l}\text { Serum IR-GIP } \\
(\mu \mathrm{g} / 1 \times 180 \mathrm{~min})\end{array}$ & $\begin{array}{l}\text { Serum IRI } \\
(\mathrm{U} / 1 \times 180 \mathrm{~min})\end{array}$ & $\begin{array}{l}\text { Serum glucose } \\
(\mathrm{g} / \mathrm{dl} \times 180 \mathrm{~min})\end{array}$ \\
\hline \multicolumn{4}{|l|}{ Oral fat $(n=9)$} \\
\hline $\begin{array}{l}\text { without } \\
\text { pancreatin }\end{array}$ & $47 \pm 4$ & - & - \\
\hline $\begin{array}{l}\text { with } \\
\text { pancreatin }\end{array}$ & $128 \pm 9^{b}$ & - & - \\
\hline \multicolumn{4}{|c|}{ Oral fat plus $N$ glucose $(n=9)$} \\
\hline pancreatin & $50 \pm 3$ & $3.5 \pm 0.3$ & $14.8 \pm 0.9$ \\
\hline $\begin{array}{l}\text { with } \\
\text { pancreatin }\end{array}$ & $85 \pm 6^{\mathrm{b}, c}$ & $7.3 \pm 0.6^{\mathrm{a}}$ & $10.1 \pm 1.0^{\mathrm{b}}$ \\
\hline \multicolumn{2}{|c|}{$I V$ glucose $(n=9)$} & $3.0 \pm 0.3$ & $16.9 \pm 1.1$ \\
\hline $\begin{array}{l}\text { with } \\
\text { pancreatin }\end{array}$ & $-10 \pm 1.4$ & $2.5 \pm 0.4^{\mathrm{d}}$ & $15.2 \pm 1.2^{\mathrm{e}}$ \\
\hline
\end{tabular}

${ }^{a} p<0.005$ between patients with chronic pancreatitis with and without pancreatin

${ }^{b} \mathrm{p}<0.01$ between patients with chronic pancreatitis with and without pancreatin

${ }^{c} \mathrm{p}<0.05$ between patients receiving oral fat and pancreatin with and without IV glucose

${ }^{\mathrm{d}} \mathrm{p}<0.005$ between patients receiving IV glucose and pancreatin alone or together with an oral fat load

${ }^{e} \mathrm{p}<0.02$ between patients receiving IV glucose and pancreatin alone or together with an oral fat load

fatty acids, rather than glycerol, stimulate GIP release [23]. Fatty acids must be absorbed and metabolised by the GIP producing cell. This can be deduced from observations in coeliac disease $[11,12]$ when fat digestion is intact but GIP release grossly impaired. The exact mechanism whereby the absorptive events trigger GIP release is not known.

It is possible that pancreatin exerts its effect partially by accelerating the rate of gastric emptying. Against this is the observation that pancreatin does not change glucose-induced IR-GIP release (Table 2). Furthermore, it has been shown that the gastric emptying rate is accelerated in patients with massive steatorrhea and slowed down by enzyme substitution [25]. The significance of absorption for initiating IR-GIP secretion is underlined by the results of the oral glucose load. Glucose does not need to be hydrolysed before being absorbed. Therefore, its effect on IR-GIP release is not enhanced by pancreatin. In turn, this experiment demonstrates that pancreatin as such does not augment nutrientstimulated GIP secretion. 
The enhanced IRI response to oral fat plus pancreatin during IV glucose (Fig. 3) indicates that the incretin effect of oral fat is dependent on digestion and absorption. The simultaneous enhancement of IR-GIP and IRI response after improved fat digestion (Figs. 2 and 3) suggests that both are related. However the participation of other gut factors with incretin activity cannot be excluded. If such as yet unidentified gut factors [26] are involved in the pancreatin induced enhancement of IRI release in patients with pancreatogenic steatorrhea, the release of these factors must also be stimulated by fat digestion and not by the presence of fat in the gut.

Hyperglycaemia and elevation of endogenous insulin levels with IV glucose infusion inhibits fatinduced secretion of IR-GIP by a negative feedback mechanism $[1,3,27,28]$. An inhibitory effect of IV glucose occurred in this study only when pancreatin was added to the fat load. Under this condition the insulin response was more than doubled and the glucose increment blunted. This suggests that the inhibitory effect of IV glucose infusion on IR-GIP is related to the rate of glucose metabolism [29].

Besides GIP, motilin [30], enteroglucagon [31], secretin [32], cholecystokinin [33] and gastrin [34] are released following nutrient ingestion. No information regarding the secretion of motilin and enteroglucagon in chronic pancreatitis is available. The release of gastrin [14, 35] and secretin [36] after food intake is not altered in chronic pancreatitis whereas hypersecretion of cholecystokinin has been reported [37]. The decreased response of pancreatic polypeptide observed in chronic pancreatitis with massive steatorrhea [38] has been explained by loss of functioning PP-cells in the diseased pancreas. Thus, GIP is the only known gut hormone whose secretion is impaired with maldigestion.

Diabetes in patients with chronic pancreatitis is explained by the simultaneous damage of endocrine and exocrine pancreatic tissue. Exocrine and endocrine pancreatic insufficiency are closely related [39]. The present results show that in chronic pancreatitics with massive steatorrhea but without overt diabetes insulin secretion and glucose tolerance during a mixed meal can be markedly enhanced by improvement of digestion. This indicates that in a selected group of chronic pancreatitics the insulin reserve is big enough to respond to increased GIP secretion. In turn, this finding demonstrates that in these patients the impairment of glucose tolerance after a mixed meal may be due partially to the loss of an "incretin". Such cases confirm Moore's original hypothesis from the year 1906 that "in certain cases of diabetes the appearance of sugar in the urine might be due to functional disturbance occasioned by the absence of an intestinal excitant of the internal secretion" [40].
Acknowledgements. This work was supported by the Deutsche Forschungsgemeinschaft, grant $\mathrm{Cr} 20 / 15$. The authors wish to thank Mrs. K. Illmer, Mrs. U. Kleinschmidt and Ms. B. Berning for expert technical assistance.

\section{References}

1. Brown JC, Dryburgh JR, Ross SA, Dupré J (1975) Identification and actions of gastric inhibitory polypeptide. Recent Prog Horm Res 31: 487-532

2. Cataland S, Crockett SE, Brown JC, Mazzaferri EL (1974) Gastric inhibitory polypeptide (GIP) stimulation by oral glucose in man. J Clin Endocrinol Metab 39: 223-228

3. Cleator JGM, Gourlay RH (1975) Release of immunoreactive gastric inhibitory polypeptide (IR-GIP) by oral ingestion of food substances. Am J Surg 130: 128-135

4. Morgan LM, Wright JW, Marks V (1979) The effect of oral galactose on GIP and insulin secretion in man. Diabetologia 16: $235-239$

5. Ross SA, Dupré J (1978) Effects of ingestion of triglyceride or galactose on secretion of gastric inhibitory polypeptide and on response to intravenous glucose in normal and diabetic subjects. Diabetes 27: 327-333

6. Falko JM, Crockett SE, Cataland S, Mazzaferri EL (1975) Gastric inhibitory polypeptide (GIP) stimulated by fat ingestion in man. J Clin Endocrinol Metab 41: 260-265

7. Thomas FB, Sinar D, Mazzaferri EL, Cataland S, Mekhjian HS, Caldwell JH, Fromkes JJ (1978) Selective release of gastric inhibitory polypeptide by intraduodenal amino acid perfusion in man. Gastroenterology 74: 1261-1265

8. Schauder P, Brown JC, Frerichs H, Creutzfeldt W (1975) Gastric inhibitory polypeptide.: effect on glucose-induced insulin release from isolated rat pancreatic islets in vitro. Diabetologia 11: $483-484$

9. Pederson RA, Brown JC (1976) The insulinotropic action of gastric inhibitory polypeptide in the perfused isolated rat pancreas. Endocrinology 99: 780-785

10. Dupré J, Ross SA, Watson D, Brown JC (1973) Stimulation of insulin secretion by gastric inhibitory polypeptide in man. J Clin Endocrinol Metab 37: 826-828

11. Creutzfeldt W, Ebert R, Arnold R, Frerichs H, Brown JC (1976) Gastric inhibitory polypeptide (GIP), gastrin and insulin: response to test meal in coeliac disease and after duodenopancreatectomy. Diabetologia 12: 279-286

12. Besterman HS, Bloom SR, Sarson DL, Blackburn AM, Johnston DI, Patel HR, Stewart JS, Modigliani R, Guerin S, Mallison CN (1978) Gut-hormone profile in coeliac disease. Lancet I: $785-788$

13. Sjölund K, Alumets J, Berg N-O, Hakanson R, Sundler F (1979) Duodenal endocrine cells in adults coeliac disease. Gut 20: $547-552$

14. Ebert R, Creutzfeldt W, Brown JC, Frerichs H, Arnold R (1976) Response of gastric inhibitory polypeptide (GIP) to test meal in chronic pancreatitis-relationship to endocrine and exocrine insufficiency. Diabetologia 12: 609-612

15. Creutzfeldt W (1979) The incretin concept today. Diabetologia 16: $75-85$

16. Melani F, Ditschuneit H, Bartelt KM, Friedrich H, Pfeiffer EF (1965) Über die radioimmunologische Bestimmung von Insulin im Blut. Klin Wochenschr 43: 1000-1007

17. Kuzio M, Dryburgh JR, Malloy KM, Brown JC (1974) Radioimmunoassay for gastric inhibitory polypeptide. Gastroenterology 66: 357-364

18. Ebert R, Illmer K, Creutzfeldt W (1979) Release of gastric inhibitory polypeptide (GIP) by intraduodenal acidification in 
rats and humans and abolishment of the incretin effect of acid by GIP-antiserum in rats. Gastroenterology 76: 515-523

19. Finke U, Ebert R, Creutzfeldt W (1978) Different forms of immunoreactive gastric inhibitory polypeptide (IR-GIP) in human serum and intestinal mucosa. Diabetologia 15: 232

20. van de Kamer, JH, ten Bokkel Huinink H, Weijers HA (1959) Rapid method for the determination of fat in feces. J Biol Chem 177: 347-355

21. Documenta Geigy (1962) Scientific Tables, 6th ed. Geigy, Manchester, 624

22. Creutzfeldt W, Ebert R (1977) Release of gastric inhibitory polypeptide (GIP) to a test meal under normal and pathological conditions in man. In: Bajaj JS (ed) Diabetes. Int Congr Ser 413. Excerpta Medica, Amsterdam, p 63-75

23. Creutzfeldt W, Ebert R, Willms B, Frerichs H, Brown JC (1978) Gastric inhibitory polypeptide (GIP) and insulin in obesity: increased response to stimulation and defective feedback control of serum levels. Diabetologia 14: 15-24

24. Köbberling J, Creutzfeld W (1970), Comparison of different methods for the evaluation of the oral glucose tolerance test. Diabetes 19: 870-877

25. Long WB, Weiss JB (1974) Rapid gastric emptying of fatty meals in pancreatic insufficiency. Gastroenterology 67: 920-924

26. Moody AJ (1977) Insulin releasing polypeptides. In: Bajaj JS (ed) Diabetes. Int Congr Ser 413. Excerpta Medica, Amsterdam, $p$ 76-82

27. Crockett SE, Cataland S, Falko JM, Mazzaferri EL (1976) The insulinotropic effect of endogenous gastric inhibitory polypeptide in normal subjects. J Clin Endocrinol Metab 42: 1098-1103

28. Ebert R, Frerichs H, Creutzfeldt W (1979) Impaired feedback control of fat induced gastric inhibitory polypeptide (GIP) secretion by insulin in obesity and glucose intolerance. Eur J Clin Invest 9: 129-135

29. Creutzfeldt W, Talaulicar M, Ebert R, Willms B (1980) Inhibition of gastric inhibitory polypeptide (GIP) release by insulin and glucose in juvenile diabetes. Diabetes 29: 140-145

30. Christofides ND, Bloom SR, Besterman HS, Adrian TE, Ghatei MA (1979) Release of motilin by oral and intravenous nutrients in man. Gut 20: 102-106

31. Holst JJ (1978) Physiology of enteric glucagon-like substances. In: Bloom SR (ed) Gut hormones. Churchill-Livingstone, Edinburgh London New York, p 383-386
32. Fahrenkrug J, Schaffalitzky de Muckadell OB (1977) Plasma secretin concentration in man: effect of intraduodenal glucose, fat, amino acids, ethanol, $\mathrm{HCl}$, or ingestion of a meal. Eur $\mathrm{J}$ Clin Invest 7: 199-201

33. Go VLW (1978) The physiology of cholecystokinin. In: Bloom SR (ed) Gut hormones. Churchill-Livingstone, Edinburgh London New York, p 203-207

34. Blair EL, Grund ER, Lund PK, Reed JD, Sanders DJ, Thompson MH, Venables CW (1978) Gastrin release. In: Bloom SR (ed) Gut hormones. Churchill-Livingstone, Edinburgh London New York, p 151-155

35. Kalk WJ, Vinik AI, Bank S, Hayes JR, Ardill J, Buchanan KD, Keller P, Jackson WPU (1974) Plasma gastrin responses to arginine in chronic pancreatitis. Diabetes 23: 264-26

36. Pelletier MJ, Chayvialle JA, Descos L, Kiriacos J, Lambert R (1976) Hydrochloric acid induced secretin release and half-life of exogenous secretin in patients with chronic pancreatitis. Scand J Gastroenterol 11: 14

37. Harvey RF, Dowsett L, Hartog M, Read AE (1973) A radioimmunoassay for cholecystokinin-pancreozymin. Lancet II: $826-828$

38. Adrian TE, Besterman HS, Mallinson CN, Garalotis C, Bloom SR (1979) Impaired pancreatic polypeptide release in chronic pancreatitis with steatorrhoea. Gut 20: 98-101

39. Kalk WJ, Vinik AI, Jackson WPU, Bank S (1979) Insulin secretion and pancreatic exocrine function in patients with chronic pancreatitis. Diabetologia 16: 347-351

40. Moore B, Edie ES, Abram JH (1906) On the treatment of diabetes mellitus by acid extract of duodenal mucous membrane. Biochem J 1: 28-38

Received: November 5, 1979, and in revised form: May 6, 1980

Prof. Dr. W. Creutzfeldt

Medizinische Universitätsklinik

Robert-Koch-Straße 40

D-3400 Göttingen

Federal Republic of Germany 